\title{
Stress responses of transportation on red tilapia which given feed containing chromium
}

\section{Respons stres transportasi pada ikan nila merah yang diberikan pakan berkromium}

\author{
Rakhmawati $^{12^{*}}$, Muhammad Agus Suprayudi ${ }^{3}$, Mia Setiawati ${ }^{3}$, Widanarni ${ }^{3}$, Muhammad \\ Zairin Junior ${ }^{3}$, Dedi Jusadi ${ }^{3}$
}

${ }^{1}$ Postgraduate student of Bogor Agricultural University, ${ }^{2}$ Study Programme of Aquaculture, Lampung State Polytechnic, ${ }^{3}$ Aquaculture Departement, Faculty of Fisheries and Marine Sciences, Bogor Agricultural University

*Email: rakhmawati@polinela.ac.id

(Received August 14, 2017; Accepted February 1, 2018)

\begin{abstract}
This study was conducted to evaluate stress responses of transportation on red tilapia Oreochromis sp. which given feed containing chromium. Three isonitrogenous and isocaloric experimental feeds were prepared, these diets were control (without chromium), CrPic $1 \mathrm{mg} / \mathrm{kg}$, and CrYst $2 \mathrm{mg} / \mathrm{kg}$ supplementation in feed, all group were arranged triplicate. Satiation feeding was done three times a day. After a 60-day feeding experiment, the experimental fishes were fasted and distributed in polyethylene bags ( $\mathrm{N}=60 \mathrm{fish} / \mathrm{bag})$ containing $3 \mathrm{~L}$ of water, subjected to condition of transport simulation for 13 hours. Survival rate, levels of plasma cortisol, blood glucose, superoxide dismutase (SOD), and malondialdehyde (MDA) enzyme were observed at before transportation, after transportation, one day, and two days after transportation. The result showed that chromium supplementation reduced the levels of plasma cortisol before and after transportation, one day, and two days after transportation. Also, it decreased blood glucose compared with control significantly before transportation and one day after transportation. The SOD enzyme concentration increased significantly after fish was fed with feed containing chromium for 30 days, while the MDA enzyme concentration increased significantly after two days of transportation. However, there was no significant difference in the survival of red tilapia between treatments. The best result was obtained in the treatment of fish which fed with feed containing chromium. A $1 \mathrm{mg} / \mathrm{kg}$ of CrPic supplementation and $2 \mathrm{mg} / \mathrm{kg}$ CrYst increased the body resistance in red tilapia by decreasing the negative effect of stress while transportation.
\end{abstract}

Keywords: stress, transportation, red tilapia, chromium

\begin{abstract}
ABSTRAK
Penelitian dilakukan untuk mengevaluasi respons stres transportasi ikan nila merah Oreochromis sp. yang diberikan pakan yang mengandung kromium. Pada penelitian ini digunakan tiga jenis pakan, terdiri atas pakan tanpa suplementasi kromium (kontrol), pakan bersuplementasi kromium pikolinat (CrPic $1 \mathrm{mg} / \mathrm{kg}$ ), dan kromium yeast (CrYst $2 \mathrm{mg} / \mathrm{kg}$ ), semua perlakuan diulang sebanyak tiga ulangan. Pemberian pakan sebanyak tiga kali sehari dan dilakukan secara at satiation. Setelah 30 hari pemeliharaan, ikan uji dipuasakan dan didistribusikan dalam plastik polietilen ( $\mathrm{N}=60$ ekor ikan/kantong plastik) yang berisi $3 \mathrm{~L}$ air, dilakukan dengan simulasi transportasi selama 13 jam. Parameter yang diamati pada penelitian ini adalah kelangsungan hidup, kortisol, glukosa darah, enzim superoksida dismustase (SOD), dan malondialdehida (MDA) saat sebelum transportasi, sesaat setelah transportasi, sehari, dan dua hari setelah transportasi. Hasil yang didapatkan adalah suplementasi kromium menurunkan konsentrasi kortisol secara signifikan sebelum transportasi, sesaat, sehari, dan dua hari setelah transportasi. Suplementasi kromium menurunkan glukosa darah secara signifikan pada saat sebelum transportasi dan sehari setelah transportasi. Konsentrasi enzim SOD meningkat secara signifikan setelah pemberian pakan bersuplementasi kromium selama 30 hari, sedangkan konsentrasi enzim MDA meningkat secara signifikan setelah dua hari transportasi pada ikan yang diberi pakan bersuplementasi kromium. Namun, tidak ada perbedaan yang signifikan pada kelangsungan hidup ikan nila merah antarperlakuan. Hasil terbaik diperoleh pada perlakuan ikan dengan suplementasi kromium. Suplementasi $1 \mathrm{mg} / \mathrm{kg}$ CrPic dan $2 \mathrm{mg} / \mathrm{kg}$ CrYst dapat meningkatkan daya tahan tubuh pada budidaya ikan nila merah dengan menurunkan pengaruh negatif stres akibat transportasi.
\end{abstract}




\section{INTRODUCTION}

Nile tilapia Oreochromis sp. is such a potential species to be developed and cultured in many regions because of high economic value (Suprayudi et al., 2013). Moreover, Nile tilapia has high tolerance towards many environmental conditions, such as $\mathrm{pH}$, temperature, nitrogen waste, low dissolved oxygen, and easy handling. Those advantages cause Nile tilapia is widely emerged and developed (Noor et al., 2010). However, the intensive growing of Nile tilapia requires excellent innovation and advanced technology in order to respond condition changes in aquaculture activity, including fish transportation.

Fish transportation consists of fresh fish transport and live fish transport. Nile tilapia transport is an important aspect because transportation is a method to transfer a number of fishes in a certain period of time, simultaneously by maintaining fish quality and high survival rate to the destination. This transportation was done on the Nile tilapia juvenile to be reared and for breeding purpose (Orina et al., 2014), and also for market size (Wyne \& Wurts, 2011). Live fish transport is quiet complicated process in aquaculture activity because it tends to change water quality in transportation media, such as carbon dioxide accumulation, ammonia, and suspended solids (Emmanuel et al., 2013). Apart from water quality, fish transportation also depends on other factors, such as a period of time, temperature, density, size of the fish, the physical condition of the fish, stress level, and packing (Iverson et al., 2005; Ashley, 2007; Tang et al., 2009). Water quality changes during transportation affects stress level and psychological changes of the fish.

Stress level is described as common psychological respond along with threatening condition. Repeating and prolonged stress condition might become negative influence towards growth and developing level, immunity, and reproduction mechanism (Schreck \& Tort, 2016). Decreasing on stress level during transportation is a crucial aspect to support survival rate and growth performance (Navarro et $a l ., 2016)$. This aspect can be done through feed supplementation, one of them is chromium $(\mathrm{Cr})$ supplementary in the feed.

The main role of chromium in fish metabolism is to help insulin through its existence on the organometallic molecule, glucose tolerance factor
(GTF) (Yan et al., 2010). Insulin metabolism affects lipid peroxidation (Refaie et al., 2009); Cr as insulin potentiator. Therefore, $\mathrm{Cr}$ is assumed functioning as an antioxidant (Lai, 2008). Some of the experiments stated that chromium supplementary is scientifically proved in reducing the negative effect of environmental stress in some livestocks. (Bahrami et al., 2012; Huang et al., 2015). Supplementary of chromium picolinate (CrPic) $1 \mathrm{mg} / \mathrm{kg}$ and Cr yeast (CrYst) $2 \mathrm{mg} / \mathrm{kg}$ were being able to increase growth performance and blood biochemical activity on red tilapia (Rakhmawati et al., 2018). This study aimed to evaluate stress level caused by transportation on red tilapia fed with chromium-containing feed.

\section{MATERIALS AND METHODS}

\section{Tested feed}

The composition of ingredient and proximate tested feed is shown in Table 1. This study used three kinds of feed with an equal amount of protein and energy, they are feed without chromium supplementary (control), feed containing $1 \mathrm{mg} / \mathrm{kg}$ chromium picolinate $(\mathrm{CrPic})$, and feed containing $2 \mathrm{mg} / \mathrm{kg} \mathrm{Cr}$ yeast (CrYst). CrPic, which is used in this study, is originally come from Sigma Aldrich and CrYst is from Alltech Chemistry Corporation. The ingredients and composition of treatment feed in this study were referred to Rakhmawati et al. (2018).

\section{Experimental fish and rearing activity}

As many of 180 monosex male red tilapia juveniles with average body weight $13.79 \pm$ $0.13 \mathrm{~g}$ and average body length $9.18 \pm 0.06 \mathrm{~cm}$ were acquired from Department of Aquaculture, IPB. Before this study was done, all of the experimental fish were reared for one week and fed using commercial feed with a protein content of $32 \%$ for acclimatization purpose to experiment condition. Furthermore, experimental fishes were randomly distributed into 12 aquaria $\left(35 \times 45 \times 90 \mathrm{~cm}^{3}\right)$ with density of 20 fishes each aquaria. Feeding activity was done three times a day with at satiation method $(08.00,12.00$, and 16.00). The experimental fish was reared for 30 days. Continuous aeration was applied with water renewal about $25 \%$ every 24 hours. The fecal matter was siphoned at 07.00 a.m. every day. During the experiment, water quality parameters were maintained on a normal level (temperature 27-28 ${ }^{\circ} \mathrm{C}$; dissolved oxygen $6.8-7.6 \mathrm{mg} / \mathrm{L} ; \mathrm{pH}$ 6.5-6.8). 
Table 1. The composition of ingredient and proximate $\mathrm{Cr}$ picolinate $(\mathrm{CrPic}) 1 \mathrm{mg} / \mathrm{kg}$ supplementary tested feed and $\mathrm{Cr}$ yeast (CrYst) $2 \mathrm{mg} / \mathrm{kg}$ supplementary tested feed.

\begin{tabular}{|c|c|c|c|}
\hline \multirow{2}{*}{ Ingredient (g/100 g) } & \multicolumn{3}{|c|}{ Chromium supplementary } \\
\hline & 0 (Control) & $1 \mathrm{mg} / \mathrm{kg} \mathrm{CrPic}$ & $2 \mathrm{mg} / \mathrm{kg} \mathrm{CrYst}$ \\
\hline Fish meal & 3 & 3 & 3 \\
\hline Soybean meal & 30 & 30 & 30 \\
\hline Meat bone meal & 15.5 & 15.5 & 15.5 \\
\hline Pollard & 42.5 & 42.5 & 42.5 \\
\hline Wheat flour & 2.68 & 2.68 & 2.68 \\
\hline Polimetilolcarbamide (PMC) & 0.2 & 0.2 & 0.2 \\
\hline Fish oil & 1.5 & 1.5 & 1.5 \\
\hline Corn oil & 2 & 2 & 2 \\
\hline Vitamin and mineral & 2.62 & 2.62 & 2.62 \\
\hline $\mathrm{CrPic}(\mathrm{mg} / \mathrm{kg})$ & 0 & 1 & 0 \\
\hline CrYst (mg/kg) & 0 & 0 & 2 \\
\hline \multicolumn{4}{|c|}{ The result of proximate analysis ( $\mathrm{g} / 100 \mathrm{~g})$ (dry weight) and feed energy } \\
\hline Protein $(\%)$ & 28.53 & 28.95 & 28.97 \\
\hline Lipid (\%) & 7.33 & 7.58 & 7.83 \\
\hline Crude fiber $(\%)$ & 12.47 & 13.29 & 12.36 \\
\hline NFE $(\%)$ & 38.74 & 36.95 & 37.96 \\
\hline Ash $(\%)$ & 14.14 & 15.59 & 15.61 \\
\hline Energy (kcal/100 g) & 438.63 & 439.36 & 442.15 \\
\hline \multicolumn{4}{|l|}{$\mathrm{Cr}$ in feed } \\
\hline $\mathrm{Cr}(\mathrm{mg} / \mathrm{kg})$ & 0.958 & 1.478 & 1.778 \\
\hline
\end{tabular}

\section{Fish transportation}

After rearing activity for 30 days, all of the fishes were fasted for 24 hours. Thereafter, transportation simulation was done for 13 hours. A number of 60 fishes was packed into polyethylene bags loaded with freshwater in density 20 fishes/L (SNI 7584: 2010). Oxygen was also infused into the polyethylene bags with comparison 2:1 for oxygen and water, respectively. When packing was finished, polyethylene bags were put in styrofoam and then it was cautiously sealed. After that, styrofoam was put into a container which loaded with water flow, so that styrofoam was moved (Budiyanti, 2010). After transportation was finished, the fishes were put back into the rearing container to be observed the survival rate and blood biochemical condition after one and two days post transportation. During sample collection, the fishes were fasted.

\section{Biochemical analysis}

Biochemical analysis consists of glucose level, plasma cortisol, superoxide dismutase (SOD) activity, and malondialdehyde (MDA). Blood sample collecting was done to quantify glucose level and plasma cortisol. The fish liver was collected to quantify enzymatic activity of SOD and MDA. Measurement of glucose level, plasma cortisol, and enzymatic activity of SOD and MDA were done before transportation, shortly after transportation, a day after, and two days after transportation. Three sample fishes each treatment were randomly taken and was anesthetized using $0.2 \mathrm{~g} / \mathrm{L}$ tricaine methanesulfonate (MS-222) (Ahmed et al., 2012). Fish blood was taken from vena caudalis using sterile syringe after the inner part was rinsed with $1 \mathrm{~mL}$ sodium citrate $3.8 \%$. Right after the blood was taken, it was put into centrifuge at $3000 \mathrm{rpm}$ for 10 minutes. The supernatant solution was collected to observed plasma biochemistry. Entirely serum was collected in a microtube and labeled, and then stored in temperature $20{ }^{\circ} \mathrm{C}$ until the analysis was conducted. Plasma cortisol quantity was determined using ELISA method from a commercial kit (DRG Cortisol ELISA EIA-1887, Germany) and plasma glucose was also determined using a calorimetric enzymatic test 
from commercial kit glucose liquicolor (Human $\mathrm{mbH}$ Germany) according to the kit procedure. Absorbance readings used spectrophotometer with wavelength $500 \mathrm{~nm}$ (HITACHI-U-2001).

MDA measurement was done using procedure according to Singh et al. (2002). As many of 0.5 $\mathrm{g}$ fresh fish liver was chopped in cold condition along with $1 \mathrm{~mL}$ phosphate buffer saline (PBS) containing $11.5 \mathrm{~g} / \mathrm{L} \mathrm{KCl}$ and $\mathrm{pH} 7.4$, all those solutions were homogeneously stirred. The homogenate was centrifuged for 20 minutes at $10000 \mathrm{rpm}$. As many as $0.5 \mathrm{~mL}$ supernatant solution was added with a mixture of $2.23 \mathrm{~mL}$ concentrated $\mathrm{HCl}, 10 \mathrm{~g}$ TCA, $0.38 \%$ TBA, and 100 $\mathrm{mL}$ of distilled water. This mixture was incubated at $80{ }^{\circ} \mathrm{C}$ for one hour. After the mixture got rather cold, the mixture was centrifuged at $3000 \mathrm{rpm}$ for 20 minutes. The supernatant solution was poured into another tube for absorbance readings with spectrophotometer $532 \mathrm{~nm}$ wavelength. TEP was used as standard solution.

SOD activity measurement was determined according to the method by Misra and Fridovich (1972). As much as $1 \mathrm{~g}$ of the chopped fish liver was added with $2 \mathrm{~mL}$ buffer phosphate $\mathrm{pH} 7.4$ and made into homogenate using tissue grinder. Thereafter, it was centrifuged at $10000 \mathrm{rpm}$ for 20 minutes. The supernatant (I) was poured into Eppendorf and SOD ready to analyze. From supernatant (I), as much as $0.25 \mathrm{~mL}$ supernatant (I) was collected to another tube and added with $0.4 \mathrm{~mL}$ chloroform and ethanol mixture (3:5), and then centrifuged at $3000 \mathrm{rpm}$ for 10 minutes. The supernatant (II) was collected as much as 100 $\mu \mathrm{L}$ and added $3 \mathrm{~mL}$ buffer carbonate $\mathrm{pH} 10.2$ in $30{ }^{\circ} \mathrm{C}$ and $100 \mu \mathrm{L}$ ephinephrine $(0.05 \mathrm{mg} / 10 \mathrm{~mL}$ $\mathrm{HCl} 0.01 \mathrm{~N}$ ) and read by spectrophotometer with wavelength $480 \mathrm{~nm}$, absorbance was read at $1^{\text {st }}$, $2^{\text {nd }}$, and $3^{\text {rd }}$ minute after epinephrine was added. Absorbance changes were used for calculation. $\mathrm{HCl} 0.01 \mathrm{~N}$ was used as blank solution. Control solution consists of $100 \mu \mathrm{L}$ of distilled water added with $3 \mathrm{~mL}$ buffer carbonate and $100 \mu \mathrm{L}$ epinephrine.

\section{Statistical analysis}

Entirely data which presented in this study was average value \pm standard error of three replications each treatment. All data were analyzed using one-way ANOVA and posthoc Duncan test using SPSS statistic ver.22. A significant difference was assumed on $\mathrm{P}<0.05$.

\section{RESULTS AND DISCUSSION}

\section{Result}

Survival rate

The survival rate of experimental fish was shown Table 2. There was no significant difference in red tilapia survival rate after 30 days of rearing, after 13 hours of transportation, one day, and two days post transportation. The survival rate of red tilapia ranged from $98.33-100 \%$.

\section{Glucose level and plasma cortisol}

Glucose level and plasma cortisol on red tilapia were shown in Table 3. CrPic and CrYst supplementary were significantly proved to reduce glucose level and plasma cortisol before transport phase, briefly after transport, and one day after transport $(\mathrm{P}<0.05)$. Each treatment had an increasing result on blood glucose level briefly after transport. One day after transport, blood glucose was noted decreasing. The most significant blood glucose decreasing on red tilapia was CrYst supplementary, while CrPic supplementary was less significant $(\mathrm{P}<0.05)$. On control treatment, blood glucose was decreased on two days after transport.

Plasma cortisol on both supplementary showed similar a result, however, control treatment was different. All treatments had increasing value on plasma cortisol briefly after transport, but both $\mathrm{Cr}$ supplementary feed treatment significantly

Table 2. Survival rate on red tilapia fed with $1 \mathrm{mg} / \mathrm{kg}$ chromium picolinate (CrPic) supplementary feed and $2 \mathrm{mg} /$ $\mathrm{kg}$ chromium yeast (CrYst) during transport stress level test.

\begin{tabular}{lccc}
\hline \multirow{2}{*}{ Monitoring time } & \multicolumn{3}{c}{ Survival rate (\%) } \\
\cline { 2 - 4 } & $100 \pm 0.00^{\mathrm{a}}$ & $100 \pm 0.00^{\mathrm{a}}$ & CrYst \\
\hline After 30-day of rearing, before & & & $100 \pm 0.00^{\mathrm{a}}$ \\
transport & $100 \pm 0.00^{\mathrm{a}}$ & $100 \pm 0.00^{\mathrm{a}}$ & $100 \pm 0.00^{\mathrm{a}}$ \\
After 13-hour transport & $100 \pm 0.00^{\mathrm{a}}$ & $100 \pm 0.00^{\mathrm{a}}$ & $100 \pm 0.00^{\mathrm{a}}$ \\
One day after transport & $98.33 \pm 2.89^{\mathrm{a}}$ & $100 \pm 0.00^{\mathrm{a}}$ & $100 \pm 0.00^{\mathrm{a}}$ \\
Two days after transport & *) The same superscript letter behind each standard error indicate no significant difference $(\mathrm{P}>0.05)$.
\end{tabular}


Table 3. Glucose level and plasma cortisol changing on red tilapia fed with $1 \mathrm{mg} / \mathrm{kg} \mathrm{Cr}$ picolinate (CrPic) and 2

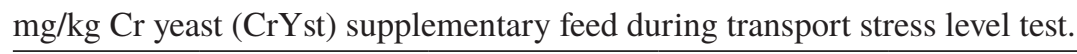

\begin{tabular}{|c|c|c|c|c|c|c|}
\hline \multirow{3}{*}{$\begin{array}{l}\text { Monitoring } \\
\text { time }\end{array}$} & \multicolumn{6}{|c|}{ Glucose level and plasma cortisol change } \\
\hline & \multicolumn{3}{|c|}{ Glucose } & \multicolumn{3}{|c|}{ Cortisol } \\
\hline & Control & CrPic & CrYst & Control & CrPic & CrYst \\
\hline $\begin{array}{l}\text { Before } \\
\text { transport }\end{array}$ & $87.70 \pm 3.28^{b}$ & $78.16 \pm 1.99^{a}$ & $82.97 \pm 1.59^{b}$ & $75.05 \pm 7.66^{\mathrm{b}}$ & $52.73 \pm 12.92^{a}$ & $39.19 \pm 4.90^{\mathrm{a}}$ \\
\hline $\begin{array}{l}\text { After } \\
\text { transport }\end{array}$ & $112.18 \pm 4.62^{a}$ & $106.43 \pm 2.27^{\mathrm{a}}$ & $107.81 \pm 1.85^{\mathrm{a}}$ & $188.30 \pm 32.2^{\mathrm{b}}$ & $79.44 \pm 9.19^{a}$ & $77.72 \pm 17.86^{a}$ \\
\hline $\begin{array}{l}\text { One day } \\
\text { after } \\
\text { transport }\end{array}$ & $101.46 \pm 1.01^{\mathrm{c}}$ & $86.57 \pm 3.66^{b}$ & $74.20 \pm 5.73^{a}$ & $172.39 \pm 42.2^{\mathrm{b}}$ & $61.53 \pm 2,99^{a}$ & $54.94 \pm 15.61^{a}$ \\
\hline $\begin{array}{l}\text { Two days } \\
\text { after } \\
\text { transport }\end{array}$ & $82.07 \pm 5.25^{\mathrm{a}}$ & $87.86 \pm 2.25^{\mathrm{a}}$ & $85.00 \pm 4.87^{\mathrm{a}}$ & $65.05 \pm 2.00^{\mathrm{a}}$ & $66.57 \pm 4.15^{a}$ & $64.12 \pm 3.75^{\mathrm{a}}$ \\
\hline
\end{tabular}

resulted in lower level of plasma cortisol $(\mathrm{P}<0.05)$ compared with control. One day after transport, plasma cortisol was decline. Decreasing plasma cortisol on red tilapia fed with $\mathrm{Cr}$ supplementary feed (CrPic and CrYst) was significantly more rapidly $(\mathrm{P}<0.05)$ compared with control. Red tilapia on control treatment was able to reduce its plasma cortisol in two days after transport.

Malondialdehyde (MDA) and superoxide dismutase (SOD) enzymatic activities

Malondialdehyde (MDA) and superoxide dismutase (SOD) enzymatic activity were shown in Table 4. MDA activity was not significantly different $(\mathrm{P}>0.05)$ before transport, briefly after transport, and one day after transport. MDA activity on two days after transport was significantly increased in both $\mathrm{Cr}$ supplementary treatment $(\mathrm{P}<0.05)$. MDA enzyme activity before transport or after a 30-day of feeding treatment was not any significant difference $(P>0.05)$. MDA activity briefly after transport didn't result in any significant difference in each feed supplementary and control treatment. Simply, one day after transport, all treatments had decreased level of MDA enzyme activity. Both feed supplementary feed had plenty more decreasing level $42.40 \%$ (CrPic) and 20.07\% (CrYst), compared with the control which had less significant decreased level $4.66 \%$. Meanwhile, MDA enzyme activity in two days after transport on $\mathrm{Cr}$ supplementary treatment was increased, while control treatment was still decreased.

Supplementation of $\mathrm{Cr}$ picolinate and $\mathrm{Cr}$ yeast was able to increase SOD enzyme activity before transport $(\mathrm{P}<0.05)$, but statistically there

Table 4. Malondialdehyde (MDA) and superoxide dismutase (SOD) enzymatic activity on red tilapia fed with 1 $\mathrm{mg} / \mathrm{kg}$ Cr picolinate (CrPic) and $2 \mathrm{mg} / \mathrm{kg} \mathrm{Cr}$ yeast (CrYst) during transport stress level test

\begin{tabular}{|c|c|c|c|c|c|c|}
\hline \multirow{3}{*}{$\begin{array}{l}\text { Monitoring } \\
\text { time }\end{array}$} & \multicolumn{6}{|c|}{ Enzyme activity } \\
\hline & \multicolumn{3}{|c|}{ Malondialdehyde } & \multicolumn{3}{|c|}{ Superoxide dismutase } \\
\hline & Control & $\mathrm{CrPic}$ & CrYst & Control & $\mathrm{CrPic}$ & CrYst \\
\hline $\begin{array}{l}\text { Before } \\
\text { transport }\end{array}$ & $19.95 \pm 7.82^{\mathrm{a}}$ & $39.35 \pm 18.27^{a}$ & $35.69 \pm 11.38^{a}$ & $4.22 \pm 0.38^{\mathrm{a}}$ & $6.58 \pm 1.34^{\mathrm{ab}}$ & $7.73 \pm 2.0^{1} b$ \\
\hline $\begin{array}{l}\text { After a } \\
\text { 13-hour } \\
\text { transport }\end{array}$ & $18.44 \pm 7.79^{a}$ & $40.97 \pm 15.87^{a}$ & $33.44 \pm 12.16^{a}$ & $6.13 \pm 2.01^{\mathrm{a}}$ & $7.11 \pm 1.54^{\mathrm{a}}$ & $5.42 \pm 0.15^{\mathrm{a}}$ \\
\hline $\begin{array}{l}\text { One day after } \\
\text { transport }\end{array}$ & $17.58 \pm 3.7^{\mathrm{a}}$ & $23.60 \pm 13.94^{a}$ & $26.73 \pm 16.93^{a}$ & $5.24 \pm 1.00^{\mathrm{a}}$ & $4.99 \pm 1.25^{\mathrm{a}}$ & $5.30 \pm 0.71^{\mathrm{a}}$ \\
\hline $\begin{array}{l}\text { Two days } \\
\text { after } \\
\text { transport }\end{array}$ & $11.69 \pm 2.98^{\mathrm{a}}$ & $31.45 \pm 7.87^{\mathrm{b}}$ & $47.16 \pm 12.86^{b}$ & $5.91 \pm 0.54^{\mathrm{a}}$ & $6.13 \pm 0.46^{\mathrm{a}}$ & $6.49 \pm 3.64^{\mathrm{a}}$ \\
\hline
\end{tabular}

*) Different superscript letter behind each standard error on the same row indicate significant difference $(\mathrm{P}<0.05)$ 
was no significant difference on SOD enzyme activity before transport, one day, and two days after transport. The highest level of SOD enzyme activity on red tilapia fed with CrYst supplementary and then $\mathrm{CrPic}$ respectively $(\mathrm{P}<0.05)$, compared with control treatment before transport. Briefly after transport, SOD activity was increased on red tilapia fed with $\mathrm{CrPic}$ supplementary feed and control treatment. One day after transport, SOD enzyme activity on red tilapia fed with CrYst supplementary feed was increased, whereas red tilapia fed with $\mathrm{CrPic}$ supplementary feed and control treatment was decreased. SOD activity was increased in two days after transport on each treatment.

\section{Discussion}

In this study, plasma cortisol changes moved proportionally with blood glucose level. Both parameters mentioned before, were essential stress indicators, plasma cortisol as primary stress indicator, while blood glucose level is secondary stress indicator (Porchas et al., 2009; Zahl et al., 2009). The hormonal stress response is an essential physiological adaptation for hemostasis mechanism. From the physiological view, stressor caused different plasma cortisol and epinephrine response for certain time. Epinephrine increases in seconds and nevermore involved in circulation, while cortisol increases in minutes to hours in responding stressor (Vijayan et al., 2010). The neuroendocrine response towards stress is characterized by an excessive level of gluconeogenesis, glycogenolysis, and insulin resistance. Hyperglycemia is caused by an increasing in liver activity, especially in stress condition. Some of cortisol metabolic impact is increase in blood glucose level through enzyme activity on gluconeogenesis and inhibition of glucose intake in peripheral tissue, such as skeletal muscle. Both epinephrine and norepinephrine induce gluconeogenesis and glycogenolysis, where norepinephrine increases glycerol supply to the liver through lipolysis (Dungan et al., 2009; Bartness et al., 2010).

Cortisol and blood glucose level increased in each treatment briefly after transport indicated stress on experimental fish. This kind of result is similar to cortisol and blood glucose level increase at $60^{\text {th }}$ and $90^{\text {th }}$ minute on tilapia after electric shock (Barreto \& Volpato, 2006), similarly when tilapia is injected with different anesthesia during stress level test (Navarro et al., 2016). This result was also shown on common carp which experienced cortisol increase, but insignificantly after a 12-hour transport (Dobsikova et al., 2009). One day after transport, cortisol was decreased. Nevertheless, cortisol on control treatment was significantly still higher than fish fed with $\mathrm{CrPic}$ and CrYst supplementary, briefly after transport, one day, and two days after transport.

When fish is exposed to a stressor, physiological responses are started with threat recognizing by the central nervous system. Cortisol secretion is started in hypothalamic-pituitary-interrenal axis along with corticotropin-releasing hormone (CRH) or corticotropin-releasing factor (CRF), especially from hypothalamus gland which induce corticotropic cell from anterior hypophysis to secrete an adrecorticotropic hormone (ACTH) (Barton, 2002). A related experiment on rainbow trout, showed that blood glucose level modulates cortisol secretion caused by ACTH on rainbow trout (Conde-Sieira et al., 2013). In vitro cortisol secretion is reinforced by the high level of glucose and decreasing on cytocrine-B (glucose transport inhibitor). It proves glicemia condition and nonpancreatic-releasing hormone. It shows that hyperglycemia is related to cortisol synthesis and its secretion under stress condition. In this mechanism, adrenaline did not only release glucose, but also as hyperglycemia signal, a prerequisite for ACTH in cortisol secretion.

Blood glucose level increased briefly after transport. In stress condition, fish needs more energy to adapt towards transport condition. Stress induces adrenaline to release energy, followed with corticosteroids (cortisol) from adaptation response; cortisol regulates longer energy distribution after adaptation process and recovers normal condition, include re-regulated set point to control hemostasis (Koolhaas et al., 2011). Overall, stress response obtained temporarily hyperglycemia in providing energy source against stress. Nerve system is direct functions towards chromaffin cell in glycolytic adrenaline secretion on $2^{\text {nd }}$ minute basis. After that, cortisol takes over to maintain hyperglycemia for some minutes to hours and enable redistribution and reallocate adaptive energy (Koolhaas et al., 2010; 2011).

One day after transport, blood glucose level was decreasing. The most significant decreasing of blood glucose level occurred on CrYst supplementary feed treatment and CrPic supplementary feed treatment respectively, compared with control treatment. Decreasing of blood glucose level in control treatment occurred two days after transport. Therefore, CrPic and 
CrYst supplementary feed enable to reduce blood glucose level more rapid than without $\mathrm{Cr}$ supplementation. Chromium is potential to induce insulin sensitivity so that more effective in utilizing glucose, also found that CrYst had more insulin sensitivity compared with $\mathrm{CrPic}$ (Rakhmawati et al., 2018). Yeast contained in CrYst held an essential role in glucose and insulin mechanism (Liu et al., 2015).

Two days after transport, blood glucose level was increasing in $\mathrm{Cr}$ supplementary treatment after stress response was eliminated. A possible cause was gluconeogenesis mechanism in order to recover energy loss while fasting. In the beginning of fasting phase, cortisol induced gluconeogenesis (glucose production from noncarbohydrate source) and activated anti-stress and anti-inflammatory path. Cortisol also contributed on liver and muscle glyconeolysis (glycogen to glucose-1-phosphate and glucose) (Martin \& Crump, 2003). However, at the end of fasting phase, cortisol increased glycogenesis, liver took over unused glucose molecule by peripheral tissue and turned it into glycogen deposit that will be used during fasting phase (Baynes \& Dominiczak, 2009). Furthermore, cortisol against insulin and contributed to insulin resistance by reducing glucose transporter translocation, especially glucose transporter which sensitive to insulin (GLUT) -4 to the cell membrane (Brown \& Brown, 2012).

Stress was caused free radical production which potentially destructs cell membrane produced by binary unsaturated fatty acid peroxidation in a membrane cell. The peroxidation lipid expressed by MDA enzyme activity (Talas \& Duran, 2012). MDA value on experimental fish fed by $\mathrm{CrPic}$ and CrYst supplementary feed reared for 30 days was not significantly different compared control treatment, however, it had a lot more decreasing in MDA enzyme activity one day after transport. It was assumed caused by chromium stimulatory on insulin activity. Chromium held an important role in increasing insulin sensitivity and affect major cells related to insulin activity (El-Fattah, 2016). Supplementary of $2 \mathrm{mg} / \mathrm{kg}$ CrYst and $1 \mathrm{mg} / \mathrm{kg}$ $\mathrm{CrPic}$ significantly increased insulin sensitivity on red tilapia. Both supplementary treatment increased glucose intake and its utilization in the cell (Rakhmawati et al., 2018). Insulin also increases lipid transport from triglyceride and push it to be catabolized, so that lipoprotein lipase activity in plasma will be increased (Yan et al., 2008). Therefore, chromium supplementary will decrease oxidative damage caused by stress.

In this study, SOD activity after 30 days of feeding $\mathrm{CrPic}$ and CrYst supplementary feed is significantly increased compared to control treatment. It showed that chromium is potentially increased supply and SOD antioxidants activity. SOD enzyme is one of the most important antioxidants to prevent oxidative stress. SOD enzyme functioned as a free radical reducer, so that cell damages could be avoided (Ognjanovic et al., 2008; Li et al., 2011) and it worked by cleaning free radical or reactive oxygen species (ROS) enzymatically and turn it into more a stable product. SOD enzyme catalyzed superoxide dismutase reaction $\left(\mathrm{O}^{2-}\right)$ into hydrogen peroxide and an oxygen molecule, so that it is no longer harmful to the cell (Halliwell, 2006).

The antioxidant and anti-inflammatory activity of $\mathrm{CrPic}$ has been studied in some experiments and explainable in many mechanisms, one of them is induced the decreasing of nitrite serum production, which inhibits nitrite reaction with superoxide and reduces peroxynitrite production (Cefalu et al., 2010; Seif, 2015). Similarly to CrYst, yeast contained in the feed was assumed to affect antioxidant activity. Mannan oligosaccharide (MOS) is glucomannoproteins complex which originally comes from Saccharomyces cervesiae cell wall (Sohn et al., 2000). Mannose receptor (MR) is endocytic receptor expressed by macrophage and endothelium cell which recognized glycoprotein and glycan microbe ligand (Ringo et al., 2010; 2014). Grisdale-Helland et al. (2008) evaluated feed effect which contains $10 \mathrm{~g} / \mathrm{kg}$ MOS on Atlantic salmon for 4 months. The result showed that indigestion was significantly increased. While Sang et al. $(2009$; 2011) found that MOS feeding on Marron lobster Cherax tenuimanus resulted positive effect towards immune response, survival rate, and stress response and 1 and $2 \mathrm{~g} / \mathrm{kg}$ MOS feeding significantly increase phagocytosis, anion superoxide production, and SOD activity on sea cucumber compared with non-MOS feeding (Gu et al., 2011). However, after transport, there was no significant difference in SOD concentration between treatment. It means SOD activity during stress was affected by chromium supplementation.

\section{CONCLUSION}

The present study showed that $1 \mathrm{mg} / \mathrm{kg} \mathrm{CrPic}$ and $2 \mathrm{mg} / \mathrm{kg}$ CrYst supplementary feed were the best results among treatment. Therefore, it can be 
concluded that chromium supplementary feed is profoundly able to increase immune system on red tilapia and reduce the negative impact of fish transport.

\section{REFERENCES}

Ahmed AR, Jha AN, Davies SJ. 2012. The efficacy of chromium as a growth enhancer for mirror carp Cyprinus carpio L: an integrated study using biochemical, genetic, and histological responses. Biological Trace Element Research 148: 187-197.

Ashley PJ. 2007. Fish welfare current issues in aquaculture. Applied Animal Behavior Science 104: 199-235.

Bahrami A, Moeini MM, Ghazi H, Targhibi. 2012. The effect of different levels of organic and inorganic chromium supplementation on immune function of broiler chicken under heat-stress conditions. Journal of Applied Poultry Research 21: 209-215.

Barreto RE, Volpato GL. 2006. Stress responses of the fish Nile tilapia subjected to electro shock and social stressors. Brazillian Journal Medical and Biological Research 39: 1605-1612.

Barton BA. 2002. Stress in fishes: a diversity of responses with particular reference to changes in circulating corticosteroids. Integrative and Comparative Biology 42: 517-525.

Bartness TJ, Shrestha YB, Vaughan CH, Schwartz GJ, Song CK. 2010. Sensory and sympathetic nervous system control of white adipose tissue lipolysis. Molecular Cellular Endocrinology 318: 34-43.

Baynes J, Dominiczak M. 2009. Medical biochemistry. $3^{\text {rd }}$ edition. London: Mosby Elsevier.

Boyd M. 2013. The role of supplemental chromium on glucose intolerance and insulin resistance. Topics in Clinical Nutrition 28: 171-180.

Brown DF, Brown DD. 2012. Endocrinology. In: Brown TA, Shah SJ (ed). USMLE Step 1 Secrets: Questions You Will Be Asked on USMLE Step 1, $3^{\text {rd }}$ edition. Philadelphia, PA: Elsevier.

Budiyanti. 2010. Physiological responses of tiger grouper juveniles Epinephelus fuscoguttatus as effect of utilisation of lemon grass oil in sealed transportation with high density. [Thesis]. Bogor: Institut Pertanian Bogor.

Cefalu WT, Rood P. Pinsonat J. Qin O, Sereda
L, Levitan RA, Anderson XH, Zhang JM, Martin, CK, Martin ZQ, Wang B. 2010. Characterization of the metabolic and physiologic response to chromium supplementation in subjects with type 2 diabetes mellitus. Metabolism-Clinical and Experimental 59: 755-762.

Conde-Sieira M, Alvarez R, Lo'pez-Patin MA, Míguez JM, Flik G, Soengas JL. 2013. ACTHstimulated cortisol release from head kidney of rainbow trout is modulated by glucose concentration. Journal of Experimental Biology 216: 554-567.

Dobsikova R, Svobodova Z, Blahov J, Modra H, Velíšek J. 2009. The effect of transport on biochemical and haematological indices of common carp Cyprinus carpio L. Czech Journal of Animal Science 54: 510-518.

Dungan K, Braithwaite SS, Preiser JC. 2009. Stress hyperglycemia. Lancet 373: 1798-1807.

El Fattah AAE. 2016. Effect of chromium supplementation on insulin resistance and weight reduction in polycystic ovarian syndrome cases. Sikkim Manipal University Medical Journal 3: 324-334.

Emmanuel BE, Fayinka DO, Aladetohun NF. 2013. Transportation and the effects of stocking density on the survival and growth of Nile tilapia Oreochromis niloticus (Linnaeus). World Journal Agricultural Sciences 1: 001-007.

Gorissen M, Bernier NJ, Manuel R, de Gelder S, Metz JR, Huising MO. 2012. Recombinant human leptin attenuates stress axis activity in common carp Cyprinus carpio L.. General and Comparative Endocrinology 178: 75-81.

Grisdale-Helland B, Helland SJ, Gatlin III DM. 2008. Theeffectsofdietarysupplementation with mannanoligosaccharide, fructooligosaccharide or galactooligosaccharide on the growth and feed utilization of Atlantic salmon Salmo salar L. Aquaculture 283: 163-167.

Gu M, Ma H, Mai K, Zhang W, Bai N, Wang X. 2011. Effects of dietary $\beta$-glucan, mannan oligosaccharide and their combinations on growth performance, immunity, and resistance against Vibrio splendidus of sea cucumber, Apostichopus japonicus. Fish and Shellfish Immunology 31: 303-309.

Halliwell B. 2006. Reactive species and antioxidants redox biology is a fundamental theme of aerobic life. Plant Physiology 141: 312-322.

Huang Y, Yang J, Xiao, Lloyd K, Lin X. 2015. 
Effects of supplemental chromium source and concentration on growth performance, carcass traits, and meat quality of broilers under heat stress conditions. Biological Trace Element Research 170: 216-223.

Iverson M, Finstad B, Mckinley RS, Eliassen RA, Carlsen KT, Evjen T. 2005. Stress responses in Atlantic salmon Salmo salar L. smolts during commercial well boat transports and effects on survival after transfer to sea. Aquaculture 243: 373-382.

Koolhaas JM, de Boer SF, Coppens CM, Buwalda B. 2010. Euroendocrinology of coping styles: towards understanding the biology of individual variation. Frontier in Neuroendocrinology 31: 307-321.

Koolhaas JM, Bartolomucci A, Buwalda B, de Boer SF, Flügge, G, Korte SM. 2011. Stress revisited: a critical evaluation of the stress concept. Neuroscience and Biobehavioural Reviews 35: 1291-1301.

Lai MH. 2008. Antioxidant effects and insulin resistanceimprovement of chromium combined with vitamin $\mathrm{C}$ and $\mathrm{E}$ supplementation for type 2 diabetes mellitus. Journal of Clinical Biochemistry and Nutrition 43: 191-198.

Li LZ, Zhou DM, Peijnenburg WJ, van Gestel CA, Jin SY, Wang YJ. 2011. Toxicity of zinc oxide nanoparticles in the earthworm, Eisenia fetida and subcellular fractionation of $\mathrm{Zn}$. Environment International 37: 1098-1104.

Liu L, Cui WM, Zhang SW, Kong FH, Pedersen MA, Wen Y, Lv JP. 2015. Effect of glucose tolerance factor (GTF) from high chromium yeast on glucose metabolism in insulin resistant 3T3-L1 adipocytes. Royal Society of Chemistry 5: 3482-3490.

Martin PA, Crump MH. 2003. The adrenal gland, In: Dooley MP, Pineda MH (Ed). McDonald's veterinary endocrinology and reproduction, $5^{\text {th }}$ edition. Ames, Iowa: Iowa State Press.

Navarro RD, França RP, Paludo GR , Bizarro YWS, Silva RF, Navarro FKSP. 2016. Physiological and hematological responses of Nile tilapia Oreochromis niloticus to different anesthetics during simulated transport conditions. Actascitechnol 38: 301-306.

Noor EL, Deen AIE, Mona SZ. 2010. Impact of climatic changes (oxygen and temperature) on growth and survival rate of Nile tilapia Oreochromis niloticus. Report and Opinion 2: 192-195.

Ognjanovic BI, Markovic SD, Pavlovic SZ,
Zikic RV, Stajn AS, Saicic ZS. 2008. Effect of chronic cadmium exposure on antioxidant defense system in some tissues of rats: protective effect of selenium. Physiological Research 57: 403-411.

Orina PS, Munguti JM, Opiyo MA, Karisa HC. 2014. Optimization of seed and broodstock transport densities for improved survival of cultured Nile tilapia Oreochromis niloticus, L. 1758. International Journal of Fisheries and Aquatic Studies 1: 157-161.

Porchas M, Córdova MLR, Enriquez RR. 2009. Cortisol and glucose: reliable indicators of fish stress. Pan-American Journal of Aquatic Sciences 4: 158-178.

Rakhmawati R, Suprayudi MA, Setiawati M, Widanarni W, Junior MZ, Jusadi D. 2018. Bioefficacy of dietary chromium picolinate and chromium yeast on growth performance and blood biochemical in red tilapia, Oreochromis niloticus (Linnaeus). Aquaculture Research 49: 839-846.

Refaie FM, Esmat AY, Mohamed AF, Nour WHA. 2009. Effect of chromium supplementation on the diabetes induced-oxidative stress in liver and brain of adult rats. Biometals 22: 1075-1087.

Ring $\varnothing$ E, Olsen RE, Gifstad TØ, Dalmo RA, Amlund H, Hemre GI, Bakke AM. 2010. Prebiotics in aquaculture: a review. Aquaculture Nutrition 16: 117-136.

Ring $\varnothing$ E, Dimitroglou A, Hoseinifar SH, Davies SJ. 2014. Prebiotics in Finfish: an Update. In: Merrifield DL, Ring $\varnothing$ E, editors. Aquaculture Nutrition: Gut Health, Probiotics and Prebiotics. Oxford: Wiley-Blackwell Publishing.

Sang HM, Ky LT, Fotedar R. 2009. Dietary supplementation of mannan oligosaccharide improves the immune responses and survival of marron, Cherax tenuimanus (Smith, 1912) when challenged with different stressors. Fish and Shellfish Immunology 27: 341-348.

Sang HM, Fotedar R, Filer K. 2011. Effects of dietary mannan oligosaccharide on survival, growth, physiological condition, and immunological responses of marron Cherax tenuimanus (Smith 1912). Journal of the World Aquaculture Society 42: 230-241.

Schreck CB, Tort L. 2016. The Concept of Stress in Fish. In: Farrell AP, Brauner CJ eds. Fish Physiology Volume 35 (Biology of Stress of Fish). London: Academic Press. 
Seif AA. 2015. Chromium picolinate inhibits cholesterol-induced stimulation of platelet aggregation in hypercholesterolemic rats. Irish Journal of Medical Science 184: 291-296.

[SNI] Standar Nasional Indonesia 7584. 2010. Pengemasan benihikan nila hitam Oreochromis niloticus, Bleeker pada sarana angkutan udara. Indonesia: Badan Standar Nasional.

Sohn KS, Kim MK, Kim JD, Han IK. 2000. The role of immunostimulants in monogastric animal and fish-review. Asian-Australian Journal of Animal Science 13: 1178-1187.

Suprayudi MA, Faisal B, Setiawati M. 2013. The growth of red tilapia fed on organic-selenium supplemented diet. Jurnal Akuakultur Indonesia 12: 48-53.

Talas ZS, Duran A. 2012. The effects of slaughtering methods on physical and biochemical changes in fish. Energy Education Science and Technology Part A 29: 741-748.

Tang S, Thorarensen H, Brauner CJ, Wood CM, Farrell AP. 2009. Modeling the accumulation of $\mathrm{CO}_{2}$ during high density re-circulating transport of adult Atlantic salmon, Salmo salar, from observations aboard a sea-going commercial live-haul vessel. Aquaculture 296: 102-109.
Vijayan MM, Aluru N, Leatherland JF. 2010. Stress Response and The Role of Cortisol. In: Leatherland JF, Woo P eds. Fish Diseases and Disorders. Vol 2: Non-Infectious Disorders. Oxfordshire: CABI.

Wyne FS, Wurts WA. 2011. Transportation of warm water fish equipments and guidelines. Susquehanna River Archeological Center 390: $1-8$.

Yan X, Zhang W, Cheng J, Wang R, Kleemann DO, Zhu X, Jia Z. 2008. Effects of chromium yeast on performance, insulin activity, and lipid metabolism in lambs fed different dietary protein levels. Asian-Australasian Journal of Animal Sciences 21: 853-860.

Yan X, Zhang F, Li, Zhu X, Zhihai, Jia Z. 2010. Effects of chromium on energy metabolism in lambs fed with different dietary protein levels. Asian-Australasian Journal of Animal Sciences 23: $205-212$.

Zahl IH, Kiessling A, Samuelsen OB, Hansen MK. 2009. Anaesthesia of Atlantic cod Gadus morhua-effect of pre-anaesthetic sedation, and importance of body weight, temperature and stress. Aquaculture 295: 52-59. 